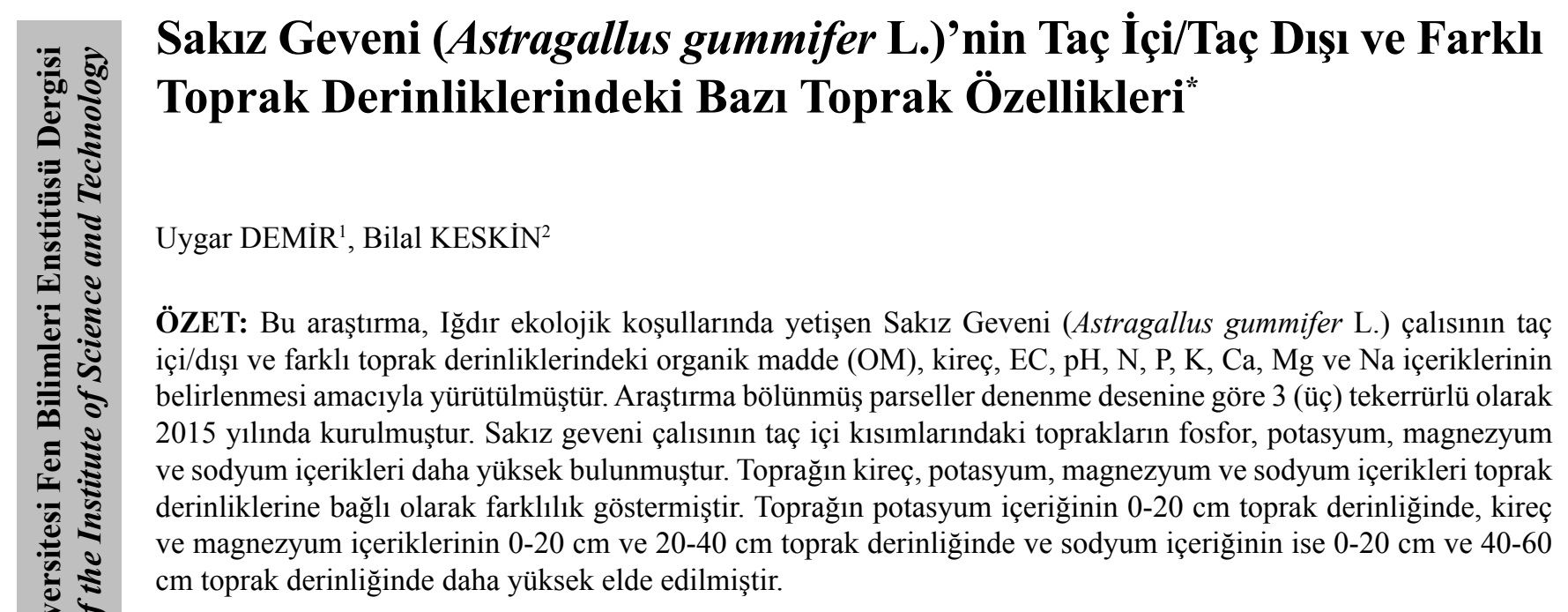

Anahtar Kelimeler: Sakız geveni, çalı, toprak özellikleri

\title{
Some Soil Properties in Inside/Outside of Canopy and Different Soil Depth of Gum Tragacanth (Astragallus gummifer L.)
}

\begin{abstract}
This research was carried out to determine organic matter (OM), lime, EC, pH, N, P, K, Ca, Mg and $\mathrm{Na}$ content inside and outside of canopy and in different soil depths of gum tragacanth (Astragallus gummifer L.) spontaneously grown in Igdir ecological conditions. The research was established according to split plot experiment design with 3 (three) replications in 2015. Phosphorus, potassium, magnesium and sodium contents of soils in canopy of gum tragacanth (Astragallus gummifer L.) were higher. Clay, lime, potassium, magnesium and sodium contents varied depending on the soil depth. The potassium content of the soil in the $0-20 \mathrm{~cm}$ soil depth, lime and magnesium content in the $0-20 \mathrm{~cm}$ and $20-40 \mathrm{~cm}$ soil depth and sodium content in $0-20 \mathrm{~cm}$ and $40-60 \mathrm{~cm}$ soil depth was higher.
\end{abstract}

Keywods: Astragallus gummifer, shrub, soil characteristic

\footnotetext{
Gıda Tarım ve Hayvancılık Bakanlığı, Ağrı İl Müdürlüğü, Tarla Bitkileri, Ağrı, Türkiye

Iğdır Üniversitesi, Ziraat Fakültesi, Tarla Bitkileri Bölümü, Iğdır, Türkiye

Sorumlu yazar/Corresponding Author: Bilal KESKİN, bilalkeskin66@yahoo.com

Bu çalışma Uygar DEMİR'in Yüksek Lisans Tezinin bir bölümüdür.
} 


\section{GİRIŞ}

Ülkemizde meraların otlatma mevsimlerinin dışında kontrolsüz ve aşırı kullanımları zamanla özelliklerinin kaybolmasına ve hatta meraların erozyona maruz kalmasına neden olmuştur. Ülkemizde mera alanlarının tarım arazilerine dönüştürülüp, yıllarca üretimde kullanıldıklarını da görmekteyiz. Yapıları gereği eğimli olan bu arazilerden yeteri kadar performans alınmayınca da terk edildikleri olmuştur (Balabanlı ve ark., 2005; Doğan, 1995). Ülkemizdeki vasıflarını kaybetmiş orta sınıf meralar için otlatmanın düzenlenmesi, gübreleme, çeşit arttırılması, yabancı ot mücadelesi gibi destekleyici tedbirler her firsatta dile getirilmektedir. Fakat çölleşmeye maruz kalmış, özellikle üst toprağını yitirmiş zayıf meralar için herhangi bir yöntem ortaya konulmamıştır. Bu tip meralar için dünyada en çok uygulanan yöntem çalı türlerinin kullanımıdır.

Keçilerin en iyi şekilde değerlendirdiği türler odunsu türlerdir (Temel ve Kır, 2015) ve otlatmanın keçilerle yapılması durumunda, çalı türlerinin beslenme değeri genel olarak yeterli olmakta, sadece kış dönemindeki protein açığını kapatmak için yeterli derecede ek yem verilmesi gerekmektedir. Ayrıca çalılar otsu türlerin kuruduğu dönemlerde otlayan hayvanlar için her zaman yeşil yem imkânı sağlamaktadır (Temel ve Tan, 2011; Dökülgen ve Temel, 2015). Dolayısı ile çalılık alanların otlatma sistemlerine dâhil edilmesi durumunda hem otlatma süresi uzatılmış olunacak hem de kaba yem masrafları azaltıldığı için daha kârlı bir hayvancılık yapılmış olunacaktır (Alatürk ve ark., 2014).

Geven küresel 1sınma ve çölleşmenin tehdidi altındaki dünyamızda muhafaza altına alınması gereken bir bitkidir. Ekonomik açıdan gevenin birçok kullanım alanı vardır. Geven eğimli alanlarda toprağı korur, biyoçeşitliliği sürdürür, arıcılıkta aromasından faydalanılır, bazı hastalıkların tedavisinde gevenden yararlanılır. Bunların yanı sıra eczacılıkta, boya ve dokuma sanayisinde önemli derecede kullanım alanına sahiptir (Kadıŏlu ve ark., 2008).

Ekolojik risk faktörü gevenlerin biyolojik çeşitliliğini azaltan önemli unsurlardandır. Gevenlerin korunması için bu risk faktörünün ortadan kaldırılması gerekmektedir. Küresel ısınmadan dolayı hayvan ve bitki yaşam alanlarının korunması ve topraklarımızın yerinde kalması için doğal bitki örtüsünün zarar görmemesi gerekmektedir. Gevenlerin bu konuda da önemli payları vardır (Kadığlu ve ark., 2008).

Bazı geven türlerinin 4 ile 6 adedi bir katır yüküne eşit olup, toprakta da geniş yer kapladıklarından dolayı toprağı korumakta ve toprağın sürüklenmesini engellemektedir. Genellikle kurak ve ağaçsız alanlarda, 3-5 m derinliğe kadar inen geven köklerinin erozyon önleyici özellikleri de vardır (Kadığlu ve ark., 2008; Kaçmaz, 2007).

Bölgede yapılan gözlemlerde küçükbaş hayvanlar Sakız Gevenini yoğun bir şekilde otlandıkları görülmüsştür. Özellikle rüzgâr erozyon sahasında yetişen bu tür ayrıca, bölgedeki rüzgâr erozyonunun önlenmesinde önemli bir rol oynamaktadır. Yine bu bitkiler köylüler tarafindan sökülerek yakacak olarak da kullanılmaktadır.

Çalılar hayvanlar, ekolojik denge ve toprak verimliliğinin devamı açısından çok önemli bir yere sahiptir. Çalılar kökleri ve yaprakları vasıtası ile toprağa bol miktarda organik madde bırakırlar. Bunun yanında toprağın fiziksel, kimyasal ve biyolojik dengelerini de düzeltirler (Parlak ve ark., 2012). Sakız Geveni çalısının da taç içi kısmındaki organik madde miktarı $\% 0.22$ ile taç dışına göre daha fazla çıkmıştır. Bunun yanında, çalıların kök kısımlarında açık alanlara göre daha fazla mikroorganizmanın olması da toprağın organik madde ve azotunu arttırmaktadır (Aguilera et al., 1999).

Parlak ve ark. (2012), Akdeniz iklim kuşağının makili alanlarında karaçalı, mazı meşesi, kermes meşesi, akçakesme, katran ardıcı çalıları üzerinde yaptıkları çalışmada taç içi toprak örneklerinde $\mathrm{N}, \mathrm{K}, \mathrm{Ca}, \mathrm{Mg}$ ve Na miktarlarının fazla olduğunu belirlemişlerdir. Çalıların toprakların kimyasal ve fiziksel özelliklerini iyileştirdiği ve toprak verimliliğine önemli katkılar sağladığı söylenebilir.

$\mathrm{Bu}$ araştırma, Iğdır ekolojik koşullarında yetişen Sakız Geveni (Astragallus gummifer L.) çalısının taç içi ve taç dışındaki toprakların organik madde, kireç, $\mathrm{EC}, \mathrm{pH}, \mathrm{N}, \mathrm{P}, \mathrm{K}, \mathrm{Ca}, \mathrm{Mg}$ ve $\mathrm{Na}$ içeriklerin belirlenmesi amaciyla yürütülmüştür. 


\section{MATERYAL ve YÖNTEM}

Çalışma alanı, Türkiye'nin ikinci büyük rüzgâr erozyon sahası olan, aynı zamanda ekstrem iklim ve toprak şartlarının hakim olduğu Iğdır ili Aralık ilçe sınırları içerisinde kalan rüzgar erozyon sahasında yürütülmüştür. Aralık ilçesi ortalama $825 \mathrm{~m}$ rakım kotunda, $30 \mathrm{~km}$ doğu batı, 4-5 km kuzey güney uzunluğunda ve toplam 13.542 hektarlık bir alan kaplamaktadır (Özdoğan, 1976). Erozyon sahasının arazi kullanım durumu incelendiğinde 6.842 ha (\%50.5)'llk alan 2. sinif mera ve 6.700 ha (\%49.5)'llk alan ise fundalıktır (Sevim, 1999). Mevcut mera alanının \%80.7 (5.524 ha)'sinde de taşlılık sorunu vardır.

Iğdır ili, İklim özelliği yönünden Doğu Anadolu Bölgesi'nden farklı bir yap1 göstermektedir. Yazları sıcak ve kurak, kışları ise soğuktur. Denemenin kurulduğu dönemde Aralık ilçesinde meteoroloji verilerinin alındığ 1 bir istasyon bulunmadığından, mevcut çalışmada Iğdır İl merkezine ait iklim verileri kullanılmıştır. Farklı kurum ve kişilerden alınan bilgilere göre Aralık (deneme) bölgesinin Iğdır/ Merkez'e göre daha sıcak ve yă̆ış miktarının ise biraz daha düşük olduğu anlaşılmaktadır (Anonim, 2015).

Araştırma Bölünmüş Parseller deneme Deseni'ne göre üç tekerrürlü olarak 2015 yılında yürütülmüştür. Her bir tekerrürde (blokta) rastgele seçilmiş 5 Sakız Geveni çalı kümesi ve toplamda ise 3 tekerrürde 15 çalı öbeği yer almıştır. Sakız Geveni bitkisinin alındığ 1 arazinin toprak özelliklerini incelemek için bitkinin taç kısmının içinde ve taç kısmının dışında 0-20 cm, 20-40 $\mathrm{cm}$ ve 40-60 cm olmak üzere 3 (üç) toprak derinliğinde toprak numuneleri alınmıştır. Alınan bu toprak örneklerinde organik madde, kireç, EC, $\mathrm{pH}, \mathrm{N}, \mathrm{P}, \mathrm{K}, \mathrm{Ca}$, $\mathrm{Mg}$ ve Na miktarları aşağıdaki şekilde belirlenmiştir.

\section{Organik madde (OM)}

Toprakların organik madde içerikleri SmithWeldon tekniğiyle bulunmuştur (Nelson and Sommers, 1982).

\section{Kireç $\left(\mathrm{CaCO}_{3}\right)$}

Toprakların kireç içerikleri Scheibler Kalsimetresi ile volümetrik olarak saptanmıştır (Nelson, 1982).

\section{Elektriksel iletkenlik (EC dSm $\left.{ }^{-1}\right)$}

Saturasyon macunlarından elde edilen ekstraksiyon süzüklerinde elektriki kondüktivite aleti ile belirlenmiştir (Rhoades, 1982).

\section{Toprak reaksiyonu (pH)}

Toprak örneklerinin $\mathrm{pH}^{\prime} 1 \quad 1 ; 2.5$ toprak su karışımında potansiyometrik olarak cam elektrotlu $\mathrm{pH}$ - metre ile bulunmuştur (Sağlam, 1994).

\section{$\operatorname{Azot}(\mathbf{N})$}

Toprak numunelerinin azot içeriği salisilik asit+tuz karışımı ile yaş yakmaya tabi tutulduktan sonra mikro kjheldahl metoduyla bulunmuştur (Bremner and Mulvaney, 1982).

\section{Fosfor $\left(\mathrm{P}_{2} \mathbf{O}_{5}\right)$}

Toprakların elverişli fosfor içerikleri asit florürde çözünebilir fosfor mavi renk yöntemiyle belirlenmiştir (Sağlam, 1994).

\section{Değişebilir Katyonlar}

Toprakların katyon değişim kapasiteleri, örneklerde sodyum asetatla $(1 \mathrm{~N}, \mathrm{pH}=8.2)$ sodyum adsorbsiyonu sağladıktan sonra amonyum asetatla (1 $\mathrm{N}, \mathrm{pH}=7.0$ ) ekstrakstrakte edilen solüsyonlarda ICPOES Inductively Couple Plasma spectrophotometry (Perkin-Elmer, Optima 2100 DV, ICP/OES, Shelton, CT 06484-4794, USA) ile okuması yapılarak saptanmıştır (Rhoades, 1982).

\section{BULGULAR ve TARTIŞMA}

Araştırmada, Iğdır ili Aralık İlçesi rüzgar erozyon sahasında kendiliğinden yetişen Sakız Geveni çalısının taç içi/taç dişı ve farklı derinlikteki $(0-20 \mathrm{~cm}, 20-40 \mathrm{~cm}$ ve $40-60 \mathrm{~cm}$ ) toprakların organik madde, kireç, EC, $\mathrm{pH}$, $\mathrm{N}, \mathrm{P}, \mathrm{K}, \mathrm{Ca}, \mathrm{Mg}$ ve Na içeriklerine etkileri belirlenmiştir. İncelenen parametrelere ait varyans analiz sonuçları Çizelge 1'de verilmiştir.

Çizelge 1 incelendiğinde; Sakız geveni çalısını taç içi ve taç dışı kısımlarındaki toprakların organik madde içeriği, kireç içeriği, $\mathrm{pH}, \mathrm{EC}$, azot ve kalsiyum içerikleri arasında istatistiki olarak önemli bir fark olmadığı görülmüştür. Diğer taraftan taç içi ve taç dışındaki toprakların potasyum, magnezyum, sodyum içerikleri $\mathrm{p}<0.01$ ihtimal seviyesinde çok önemli, elverişli fosfor içeriği ise $\mathrm{p}<0.05$ ihtimal seviyesinde önemli bulunmuştur. 
Çizelge 1. İncelenen toprak özelliklerine ait varyans analiz tablosu

\begin{tabular}{|c|c|c|c|c|c|c|c|c|c|c|c|}
\hline \multirow{2}{*}{$\begin{array}{l}\text { Varyasyon } \\
\text { Kaynakları }\end{array}$} & \multicolumn{11}{|c|}{ F Değerleri ve Önemlilik } \\
\hline & SD & O.M & Kireç & EC & PH & $\mathbf{N}$ & $\mathbf{P}$ & $\mathbf{K}$ & $\mathbf{C a}$ & Mg & $\mathbf{N a}$ \\
\hline Tekerrür & 2 & $0.22^{\text {od }}$ & $1.25^{\text {od }}$ & $0.09^{\text {od }}$ & $0.85^{\text {öd }}$ & $0.22^{\text {od }}$ & $0.20^{\circ \mathrm{od}}$ & $0.91^{\text {öd }}$ & $0.39^{\text {od }}$ & $0.09^{\mathrm{od}}$ & $0.10^{\text {öd }}$ \\
\hline Taç İçi/Dışı & 1 & $2.15^{\text {öd }}$ & $0.22^{\text {od }}$ & $0.53^{\text {od }}$ & $1.26^{\text {od }}$ & $2.15^{\text {od }}$ & $6.76^{*}$ & $275.05^{* *}$ & $0.81^{\text {od }}$ & $28.37^{* *}$ & $37.17^{* *}$ \\
\hline Derinlik & 2 & $2.52^{\text {od }}$ & $20.20^{* *}$ & $0.37^{\text {öd }}$ & $0.28^{\text {od }}$ & $2.52^{\ddot{\mathrm{d} d}}$ & $2.65^{\text {öd }}$ & $23.30^{* *}$ & $0.68^{\text {od }}$ & $12.40^{* *}$ & $6.18^{*}$ \\
\hline İnteraksiyon & 2 & $0.84^{\ddot{d d}}$ & 1.48 & $1.09^{\text {od }}$ & $5.55^{*}$ & $0.84^{\ddot{d} \mathrm{~d}}$ & $10.77^{\text {*** }}$ & $22.64^{* *}$ & $2.19^{\text {od }}$ & $6.26^{*}$ & $6.28^{*}$ \\
\hline
\end{tabular}

** işaretli F değerleri \%1 ihtimal sınırlarında çok önemli, * işaretli F değerleri \%5 ihtimal sınırlarında önemli, öd ise önemsizdir.

Yapılan çalışmada Sakız geveni çalısının taç içi ve dışından alınan toprak örneklerinin organik madde, kireç, EC, pH, N, P, K, Ca, $\mathrm{Mg}$ ve $\mathrm{Na}$ içerikleri belirlenmiştir (Çizelge 2, 3, 4, 5). En yüksek fosfor, potasyum, magnezyum ve sodyum içerikleri sırasıyla $24.7 \mathrm{ppm}, \% 0.45, \% 0.34, \% 0.49$ ile taç içi kısmından alınan toprak örneklerinde tespit edilmiştir (Çizelge 3, 4, 5).

Çalı ve ağaçlar sahip oldukları kuvvetli kök yapıları ve toprak üzerinde oluşturdukları kanopiler sayesinde toprağın organik madde yönünden zenginleşmesini sağlamaktadırlar (Tan ve Temel, 2012). Hagos ve Smith (2005) tarafindan yapilan bir çalışmada, Acacia mellifera ssp. detinens' in taç izdüşümü alanındaki topraklarda azot, kalsiyum ve organik maddenin yüksek oranlarda olduğunu ve taç içi alandan açık alanlara doğru gidildikçe topraktaki besin durumunda farklılıkların olduğu bildirilmiştir. Belsky ve ark. (1989) tarafından yapılan araştırmada ağaçların bulunduğu alanlarda organik madde, $\mathrm{P}$, $\mathrm{K}$ ve $\mathrm{Ca}$ içeriklerinin mera alanlarına göre daha yüksek olduğu ve bunun nedeninin ağaç diplerinin daha düşük toprak sıcaklığına sahip olması ve yüksek toprak verimliliğine sahip olmasiyla ilişkilendirilmiştir. Ayrıca çalı ve ağaç türlerinin bulunduğu alanlarda kuş ve memeli canlı türlerinin yoğunlukta bulunması da bu alanlardaki toprak verimliliğini etkilemektedir (Belsky et al., 1989).
Oktay ve Temel (2015) tarafindan yapılan bir çalışmada Ebu cehil çalısının taç içi ve taç dışından alınan toprak örneklerinin özellikleri belirlenmiştir. Çalışma sonucunda araştırıcılar, Ebu Cehil çalısı taç içinde kalan toprakların EC, toplam azot, organik madde, potasyum, kalsiyum, magnezyum, sülfür, fosfor, kireç ve bikarbonatların miktarını önemli düzeyde artırdığını, ancak pH değerlerini ise düşürdüğünü ve buna ek olarak Ebu Cehil çalısının oluşturduğu kanopinin rüzgâr erozyon sahasında kalan toprakların fertilitesini (verimliliğini) önemli oranda iyileştirdiği ifade etmişlerdir.

Parlak ve ark. (2012) karaçalı, mazı meşesi, kermes meşesi, akçakesme ve katran ardıcı çalılarının taç altındaki toprakların toplam azot $(\mathrm{N})$, organik karbon $(\mathrm{C})$, katyon değişim kapasitesi (KDK), alınabilir fosfor (P), değişebilir $\mathrm{Ca}, \mathrm{Mg}$, $\mathrm{K}$ ve $\mathrm{Na}$ miktarlarının açık alandan daha yüksek olduğu tespit edilmiştir.

Çalılar ekolojik denge ve toprak verimliliğinin devamı açısından çok önemli bir yere sahiptir. Çalılar kökleri ve yaprakları vasıtası ile toprağa bol miktarda organik madde bırakırlar. Bunun yanında toprağın fiziksel, kimyasal ve biyolojik dengelerini düzeltir (Parlak ve ark., 2012). Bunun yanında, çalıların kök kısımlarında açık alanlara göre daha fazla mikroorganizmanın olması toprağın organik madde ve azotunu arttırmaktadır (Aguilera et al., 1999). 
Çizelge 2. Sakız geveni çalısının taç içi ve taç dışı farklı derinliklerinde alınan toprakların organik madde, kireç ve EC miktarındaki değişimler

\begin{tabular}{ccccccccccc}
\hline \multirow{2}{*}{ Derinlik } & \multicolumn{3}{c}{ Organik Madde (\%) } & \multicolumn{3}{c}{ Kireç (\%) } & \multicolumn{3}{c}{ EC (dS m $\left.\mathbf{~}^{-1}\right)$} \\
\cline { 2 - 10 } & Taç İçi & $\begin{array}{c}\text { Taç } \\
\text { Dışı }\end{array}$ & Ort. & Taç İçi & Taç Dışı & Ort. & Taç İçi & $\begin{array}{c}\text { Taç } \\
\text { Dışı }\end{array}$ & Ort. \\
\hline $\mathbf{0 - 2 0}$ & 0.20 & 0.20 & 0.20 & 11.6 & 12.6 & $12.1 \mathrm{a}$ & 1.74 & 1.65 & 1.69 \\
$\mathbf{2 0 - 4 0}$ & 0.22 & 0.17 & 0.19 & 13.8 & 12.4 & $13.1 \mathrm{a}$ & 1.57 & 1.88 & 1.72 \\
$\mathbf{4 0 - 6 0}$ & 0.17 & 0.14 & 0.15 & 7.34 & 6.39 & $6.86 \mathrm{~b}$ & 1.79 & 1.83 & 1.83 \\
Ort. & 0.19 & 0.17 & & 10.92 & 10.46 & & 1.78 & 1.70 & \\
\hline
\end{tabular}

Çizelge 3. Sakız geveni çalısının taç içi ve taç dışı farklı derinliklerinde alınan toprakların pH, N ve P miktarındaki değişimler

\begin{tabular}{|c|c|c|c|c|c|c|c|c|c|}
\hline \multirow{3}{*}{ Derinlik } & \multicolumn{3}{|c|}{$\mathrm{pH}\left(1: 2.5^{-1}\right)$} & \multicolumn{3}{|c|}{ Azot (\%) } & \multicolumn{3}{|c|}{ Fosfor (ppm) } \\
\hline & & Taç & & & & & & Taç & \\
\hline & Taç İçi & Dişı & Ort. & Taç İçi & Taç Dışı & Ort. & Taç İçi & Dışı & Ort. \\
\hline $0-20$ & $7.67 \mathrm{bc}$ & $8.09 \mathrm{a}$ & 7.88 & 0.010 & 0.010 & 0.010 & $26.8 \mathrm{a}$ & $15.1 \mathrm{~b}$ & 20.9 \\
\hline $20-40$ & $7.75 \mathrm{abc}$ & $8.06 \mathrm{ab}$ & 7.90 & 0.011 & 0.008 & 0.010 & $23.9 \mathrm{a}$ & $23.3 \mathrm{a}$ & 23.6 \\
\hline 40-60 & $8.00 \mathrm{abc}$ & $7.62 \mathrm{c}$ & 7.83 & 0.009 & 0.007 & 0.008 & $23.3 \mathrm{a}$ & $25.5 \mathrm{a}$ & 24.4 \\
\hline Ort. & 7.80 & 7.92 & & 0.010 & 0.008 & & $24.7 \mathrm{a}$ & $21.3 \mathrm{~b}$ & \\
\hline
\end{tabular}

Çizelge 4. Sakız geveni çalısının taç içi ve taç dışı farklı derinliklerinde alınan toprakların K, Ca ve Mg miktarındaki değişimler

\begin{tabular}{ccccccccccc}
\hline \multirow{2}{*}{ Derinlik } & \multicolumn{3}{c}{ Potasyum (\%) } & \multicolumn{3}{c}{ Kalsiyum (\%) } & \multicolumn{3}{c}{ Magnezyum (\%) } \\
\cline { 2 - 10 } & Taç İçi & Taç & Dışı & Ort. & Taç İçi & Taç Dışı & Ort. & Taç İçi & Taç Dşı & Ort. \\
\hline $\mathbf{0 - 2 0}$ & $0.59 \mathrm{a}$ & $0.17 \mathrm{~d}$ & $0.38 \mathrm{a}$ & 4.91 & 4.05 & 4.48 & $0.38 \mathrm{a}$ & $0.25 \mathrm{~b}$ & $0.32 \mathrm{a}$ \\
$\mathbf{2 0 - 4 0}$ & $0.46 \mathrm{~b}$ & $0.14 \mathrm{~d}$ & $0.30 \mathrm{~b}$ & 4.47 & 3.81 & 4.14 & $0.41 \mathrm{a}$ & $0.27 \mathrm{~b}$ & $0.34 \mathrm{a}$ \\
$\mathbf{4 0 - 6 0}$ & $0.30 \mathrm{c}$ & $0.16 \mathrm{~d}$ & $0.23 \mathrm{c}$ & 3.72 & 4.37 & 4.04 & $0.24 \mathrm{~b}$ & $0.24 \mathrm{~b}$ & $0.24 \mathrm{~b}$ \\
Ort. & $0.45 \mathrm{a}$ & $0.15 \mathrm{~b}$ & & 4.36 & 4.08 & & $0.34 \mathrm{a}$ & $0.25 \mathrm{~b}$ & \\
\hline
\end{tabular}

Çizelge 5. Sakız geveni çalısının taç içi ve taç dışı farklı derinliklerinde alınan toprakların Na miktarındaki değişimler

\begin{tabular}{lccc}
\hline \multirow{2}{*}{ Derinlik } & \multicolumn{3}{c}{ Sodyum (\%) } \\
\cline { 2 - 4 } & Taç İçi & Taç Dişı & Ort. \\
\hline $\mathbf{0 - 2 0}$ & $0.50 \mathrm{a}$ & $0.35 \mathrm{~b}$ & $0.42 \mathrm{ab}$ \\
$\mathbf{2 0 - 4 0}$ & $0.39 \mathrm{~b}$ & $0.34 \mathrm{~b}$ & $0.36 \mathrm{~b}$ \\
$\mathbf{4 0 - 6 0}$ & $0.60 \mathrm{a}$ & $0.34 \mathrm{~b}$ & $0.47 \mathrm{a}$ \\
Ort. & $0.49 \mathrm{a}$ & $0.34 \mathrm{~b}$ & \\
\hline
\end{tabular}


Farklı derinliklerde alınan toprakların Organik Madde, EC, pH, azot, fosfor ve kalsiyum miktarları arasında önemli bir fark görülmemiştir (Çizelge 1). Oysa farklı derinlikte alınan toprakların kireç, potasyum ve magnezyum içerikleri $\mathrm{p}<0.01$ ihtimal seviyesinde çok önemli, sodyum içeriği ise $\mathrm{p}<0.05$ ihtimal seviyesinde önemli bulunmuştur.

Toprağın potasyum içeriğinin $0-20 \mathrm{~cm}$ toprak derinliğinde, kireç ve magnezyum içeriklerinin $0-20 \mathrm{~cm}$ ve $20-40 \mathrm{~cm}$ toprak derinliğinde ve sodyum içeriğinin ise $0-20 \mathrm{~cm}$ ve $40-60 \mathrm{~cm}$ toprak derinliğinde daha yüksek olduğu görülmüştür. İncelenen diğer toprak özelliklerinin ise toprak derinliğinden fazla oranda bir değişikliğe uğramadığı görülmüştür.

Oktay (2014), Ebu cehil bitkisinin yoğun olarak bulunduğu alanda yaptığı çalışmada; farklı derinliklerdeki toprakların bazı özelliklerini incelemiştir. Kireç, EC, fosfor, organik madde ve azot miktarının toprak derinliklerine bağlı olarak değişiklik gösterdiğini belirlemiştir. Kireç, fosfor, organik madde ve azot miktarının yüzey topraklarda $(0-20 \mathrm{~cm}), \mathrm{EC}$ değerinin ise derin topraklarda $(40-60 \mathrm{~cm})$ daha fazla olduğunu tespit etmiştir.

Toprakların taç içi/dışı x derinlik interaksiyonuna bakıldığında $\mathrm{P}$ ve $\mathrm{K}$ içeriklerinin $\mathrm{p}<0.01$ ihtimal seviyesinde çok önemli, $\mathrm{pH}, \mathrm{Mg}$ ve $\mathrm{Na}$ içeriklerinin $\mathrm{p}<0.05$ ihtimal seviyesinde önemli olduğu görülmektedir. Toprağın organik madde, kireç, EC, azot ve kalsiyum miktarları arasında taç içi/dışı x derinlik interaksiyonu önemli olmamıştır.

Taç içi/dışı x derinlik interaksiyonu önemli olan $\mathrm{pH}, \mathrm{P}, \mathrm{K}, \mathrm{Mg}$ ve $\mathrm{Na}$ içeriklerine ait interaksiyonu gruplandırmaları Çizelge 3, 4 ve 5'de verilmiştir.

Çizelge 3 incelendiğinde; yüzey topraklarda (0-20 $\mathrm{cm})$ ve taç dışındaki topraklarda $\mathrm{pH}$ miktarının (8.09) daha fazla olduğu, en düşük pH'nın (7.62) ise taç dışında ve daha derin $(40-60 \mathrm{~cm})$ toprak kısımlarında olduğu görülmüştür. Taç içi kısımlarda derinlik arttıkça $\mathrm{pH}$ miktarı artarken, tam tersine taç dışı kısımlarda derinlik arttıkça pH miktarında azalma gözlemlenmiştir.

Yüzey topraklarda $(0-20 \mathrm{~cm})$ ve taç içindeki topraklarda fosfor miktarının (26.8 ppm) daha fazla olduğu, en düşük fosforun (15.1 ppm) ise taç dışında ve 0-20 cm toprak derinliğinde olduğu görülmüsstür. Taç içi kısımlarda derinlik arttıkça fosfor miktarı düşerken, tam tersine taç dışı kısımlarda derinlik arttıkça fosfor miktarında artış olduğu belirlenmiştir(Çizelge 3).

Yüzey $(0-20 \mathrm{~cm})$ ve taç içindeki topraklarda potasyum miktarının $(\% 0.59)$ daha fazla olduğu, en düşük potasyumun $(\% 0.14)$ ise taç dişında ve orta derinlikteki $(20-40 \mathrm{~cm})$ topraklarda olduğu görülmüştür. Taç içi kısımlarında farklı derinliklerde alınan toprakların analizlerinde toprak derinliğinin artmasıyla potasyum içeriğinin azaldığı görülmüştür. Ancak taç dışı topraklarda derinliğe bağlı olarak potasyum içeriğinde önemli bir değişiklik olmamıştır (Çizelge 4).

Taç içinde ve $20-40 \mathrm{~cm}$ derinliğindeki toprakların magnezyum içeriğinin $(\% 0.41)$ daha fazla olduğu, en düşük magnezyum içeriğinin $(\% 0.24)$ ise hem taç içi hem de taç dışında ve daha derin $(40-60 \mathrm{~cm})$ toprak kısımlarında olduğu görülmüştür. Taç içi kısımlarında farklı derinliklerde alınan toprakların analizlerinde toprak derinliğinin artmasıyla potasyum içeriğinin önce arttığ1 sonra azaldığ görülmüştür. Ancak taç dış1 topraklarda derinliğe bağlı olarak potasyum içeriğinde çok fazla bir değişiklik olmamıştır (Çizelge 4).

Derin ve yüzey topraklarda $(40-60 \mathrm{~cm}$ ve $0-20$ $\mathrm{cm})$ ve taç içindeki topraklarda sodyum miktarının sirasıyla (\%0.60 ve \%0.50) daha fazla olduğu, en düşük sodyumun (\%0.34) ise taç dışında ve toprağın $20-40 \mathrm{~cm}$ ve 40-60 cm'lik kısımlarında olduğu görülmüştür. Taç dışı topraklarda toprak derinliğine bağlı olarak sodyum içeriğinde bir değişim olmamıştır (Çizelge 5).

\section{SONUC}

Iğdır ili Aralık ilçesi sınırları içerisinde kalan rüzgâr erozyonu bölgesinde yürütülen bu araştırmada sakız geveni (Astragalus gummifer L.) çalısı bazı toprak özelliklerine etkileri belirlenmeye çalışılmıştır. Sakız geveni çalısı toprağın fosfor, potasyum, magnezyum ve sodyum içeriklerine önemli derecede etki yaparken, incelenen diğer toprak özellikleri üzerine herhangi bir etkisi olmamıştır. Fosfor, potasyum, magnezyum ve sodyum içerikleri Sakız geveni çalısının yetiştiği taç içi kısımlarında daha fazla biriktiği görülmüştür. Diğer taraftan sakız geveni çalısının yetiştiği alanlarda farklı derinliklerinde alınan toprakların özellikleri de 
incelenmiştir. Sakız geveni çalısı toprak derinliğine bağlı olarak sadece toprağın kireç, potasyum, magnezyum ve sodyum içeriklerini önemli ölçüde değiştirmiştir. Toprağın potasyum içeriğinin $0-20 \mathrm{~cm}$ toprak derinliğinde, kireç ve magnezyum içeriklerinin $0-20 \mathrm{~cm}$ ve $20-40 \mathrm{~cm}$ toprak derinliğinde ve sodyum içeriğinin ise $0-20 \mathrm{~cm}$ ve $40-60 \mathrm{~cm}$ toprak derinliğinde daha yüksek olduğu görülmüştür.

\section{KAYNAKLAR}

Anonim, 2015. Iğdır Meteroloji İl Müdürlüğ̈̈, Iğdır.

Aguilera LE, Gutierrez JL, Meserve PL, 1999. Variation in Soil Micro-Organisms and Nutrients Underneath and Outside The Canopy of Adesmia bedwellii (Papilionaceae) Shrubs in Arid Coastal Chile Following Drught and Above Average Rainfall. Journal Arid Environ, 42, 61-70.

Alatürk F, Alpars T, Gökkuş A, Çoşkun E, Akbağ H, 2014. Bazı Çalı Türlerinin Besin Maddesi İçeriklerinin Mevsimsel Değişimi. ÇOMÜ Ziraat Fakültesi Dergisi, 2(1), 133-141.

Balabanlı C, Türk M, Yüksel O, 2005. Erozyon ve Çayır Mera İlişkileri. Süleyman Demirel Üniversitesi Orman Fakültesi Dergisi, A(2):23-34.

Belsky AJ, Amundson JG, Duxbury JM, Riha SJ, Ali AR, Mwonga SM, 1989. The effect of trees on their physical, chemical and biological environments in a semi-arid savanna in Kenya. Journal of Applied Ecology, 26(3): 1005-1024.

Bremner JM, Mulvaney CS, 1982. Nitrogen Total. Methods of Soil Analysis Part2. Chemical and Microbiological Properties Second Edition. Agronamy. No: 9 Part 2. American Society of Agronomy, İnc.Soil Science Society of America, İnc, Madison, Winconsin USA Edition pp, 597- 622.

Doğan O, 1995. Türkiye' de Toprak Kaynakları, Sorunlar ve Çözümler. Standart Çevre s. 73-79, Ankara.

Dökülgen H, Temel S, 2015. Yaprağını Döken Karaçalı (Palirus spina-christi Mill.) Türünde Yaprak ve Yaprak + Sürgünlerinin Mevsimsel Besin İçeriği Değişimi Iğdır Üni. Fen Bilimleri Enst. Der. 5(3): 57-65, 2015

Hagos, MG, Smith GN, 2005. Soil enrichment by Acacia mellifera subsp. Detinens on nutrient poor sandy soil in a semi-arid southern African savanna. Journal of Arid Environments, 61, 47-59.

Kaçmaz S, 2007. Kıymeti Bilinmeyen Bitki: Geven. Ekoloji Magazin Dergisi 13, 88- 89s.

Kadıŏglu B, Kadığlu S, Turan Y, 2008. Gevenlerin (Astragalus sp.) Faklı Kullanım Alanları ve Önemi. Alınteri Zirai Bilimler Dergisi 14 (1), 17-26.

Nelson DW, Sommers LE, 1982. Total Carbon, Organic Carbon, Organic Matter, Methods of Soil Analysis Part 2. Chemical and Microbiological Properties Second Edition. Agronamy No: 9 Part 2. Edition pp, 539-580.

Nelson RE, 1982. Carbonate and Gypsum. Methods of Soil Analysis Part 2. Chemical and Microbiological Properties Second Edition. Agronamy. No: 9 Part 2 Edition pp, 181-199.
Oktay G, 2014. Iğdır Ekolojik Koşullarında Yetişen Ebu Cehil (Calligonum polygonoides L. ssp. comosum (L’hér.)) Çalısının Yıllık Besin İçeriği Değişiminin ve Bazı Özelliklerinin Belirlenmesi, Iğdır Üniversitesi Fen Bilimleri Enstitüsü, Yüksek Lisans Tezi.

Oktay G, Temel S, 2015. Ebu Cehil (Calligonum polygonoides L.ssp. comosum (L'Her.) Çalısının Yıllık Yem Değerinin Belirlenmesi. Gaziosmanpaşa Üniversitesi Ziraat Fakültesi Dergisi, 32 (1), 30-36.

Özdoğan N, 1976. Rüzgâr Erozyonu ve Rüzgâr Erozyonu Sahalarında Alınacak Başlıca Tedbirler. Toprak Su Genel Müdürlüğü Yayınları, 306, Ankara.

Parlak M, Gökkuş A, Parlak AÖ, 2012. Çanakkale Meralarında Bazı Çalıların Toprak Özelliklerine Etkileri. Toprak Su Dergisi, 1 (2) , 88-98.

Rhoades JD, 1982. Soluble Salts. Methods of Soil Analysis. Part 2. Chemical and Microbiological Properties. 2nd Edition. Agronomy No: 9, 167-179, 1159 p, Madison, Wisconsin USA.

Sağlam MT, 1994. Toprak ve Suyun Kimyasal Analiz Yöntemleri. Trakya Üni. Tekirdağ Ziraat Fak. Yayın No; 189, Yardımcı Ders Kitab1 No, 5.

Sevim Z, 1999. Iğdır Aralık’ta Rüzgâr Erozyonu. T.C. Başbakanlık Köy Hizmetleri Genel Müdürlüğü Köy Hizmetleri Araştırma Enstitüsü, Erzurum.

Tan M, Temel S, 2012. Alternatif Yem Bitkileri. Atatürk Üniv. Ziraat Fak. Ders Yayınları No: 246,195-207, Erzurum.

Temel S, Kır AE, 2015. Bazı Çalı ve Ağaç Türlerinin Mevsimsel Dönem ve Hayvan Gruplarına Göre Otlanmada Tercih Durumlarının Belirlenmesi. Uluslararası Tarım ve Yaban Hayatı Bilimleri Dergisi, 1(1):31-39.

Temel S, Tan M, 2011. Fodder Values of Shrub Species in Maquis in Different Altitude sand Slope Aspects. The Journal of Animal and Plant Sciences (The JAPS). 21(3), 508-512. 
